Abstract THU0391 -Table 2.

\begin{tabular}{|c|c|c|c|}
\hline & $\begin{array}{c}\text { r-axSpA } \\
\text { Pooled percentage } \\
(95 \% \mathrm{CI})\end{array}$ & $\begin{array}{c}\text { nr-axSpA } \\
\text { Pooled percentage } \\
(95 \% \mathrm{Cl})\end{array}$ & RR $(95 \% \mathrm{Cl})$ \\
\hline \multicolumn{4}{|l|}{ Clinical presentation } \\
\hline Sex (male) & $69.8(66.2-72.8)$ & $53.6(49.0-58.1)$ & $1.30(1.2-1.4)$ \\
\hline Smoker & $37.7(26.9-50.0)$ & $31.1(21.6-42.6)$ & $1.18(1.1-1.3)$ \\
\hline HLAB27 positive & $76.7(71.6-81.1)$ & $71.9(66.7-76.6)$ & $1.04(0.9-1.1)$ \\
\hline Good NSAIDs response & $68.5(56.0-78.8)$ & $61.7(53.3-69.4)$ & $1.09(0.9-1.1)$ \\
\hline Peripheral arthritis & $32.8(27.6-38.5)$ & $35.2(28.9-41.9)$ & $0.87(0.8-0.9)$ \\
\hline Dactylitis & $5.6(3.9-7.9)$ & $7.6(5.5-10.5)$ & $0.64(0.5-0.8)$ \\
\hline Any enthesitis & $23.0(14.0-35.4)$ & $30.1(22.0-39.7)$ & $0.84(0.7-0.9)$ \\
\hline Uveitis & $18.0(13.4-23.8)$ & $14.3(12.0-16.9)$ & $1.31(1.1-1.6)$ \\
\hline Psoriasis & $8.5(5.6-12.8)$ & $9.3(7.4-11.7)$ & $0.98(0.8-1.1)$ \\
\hline IBD & $6.5(5.2-8.2)$ & $5.6(4.0-7.9)$ & $1.04(0.9-1.3)$ \\
\hline \multicolumn{4}{|l|}{ MRI inflammation } \\
\hline $\begin{array}{l}\text { Patients with positive MRI-SIJ } \\
\text { ASAS definition }\end{array}$ & $45.8(18.7-75.7)$ & $71.5(66.9-75.8)$ & $0.57(0.3-1.1)$ \\
\hline \multicolumn{4}{|l|}{ Structural damage } \\
\hline Patients with erosion MRI-SIJ & $70.8(41.8-89.1)$ & $41.0(19.0-67.3)$ & $1.8(1.1-3.0)$ \\
\hline $\begin{array}{l}\text { Patients with fatty lesions } \\
\text { MRI-SIJ }\end{array}$ & $79.4(56.1-92.1)$ & $51.5(28.4-74.0)$ & $1.4(1.2-1.7)$ \\
\hline \multicolumn{4}{|l|}{ Treatment } \\
\hline NSAIDs & $73.5(63.1-81.8)$ & $69.1(55.5-80.0)$ & $1.04(0.9-1.1)$ \\
\hline csDMARDs & $29.3(20.5-39.9)$ & $28.5(21.9-36.1)$ & $1.04(0.8-1.3)$ \\
\hline bDMARL & $28.7(19.7-39.7)$ & $26.2(26.1-39.6)$ & $1.08(0.9-1.3)$ \\
\hline
\end{tabular}

Disclosure of Interests: Clementina López-Medina: None declared, Sofia Ramiro Grant/research support from: MSD, Consultant for: AbbVie, Lilly, MSD, Novartis, Pfizer, Sanofi, Speakers bureau: AbbVie, Lilly, MSD, Novartis, Pfizer, Sanofi, Désirée van der Heijde Consultant for: AbbVie, Amgen, Astellas, AstraZeneca, Bristol-Myers Squibb, Boehringer Ingelheim, Celgene, Daiichi, Eli-Lilly, Galapagos, Gilead, GlaxoSmithKline, Janssen, Merck, Novartis, Pfizer, Regeneron, Roche, Sanofi, Takeda, Union Chimique Belge, maxime dougados Grant/research support from: Eli Lilly and Company, Pfizer, AbbVie, and UCB Pharma, Consultant for: Eli Lilly and Company, Pfizer, AbbVie, and UCB Pharma, Anna Moltó: None declared DOI: 10.1136/annrheumdis-2019-eular.3542

\section{THU0392 DESCRIPTIONAND PREVALENCE: OF SPONDYLOARTHRITIS IN UNSELECTED PATIENTS WITH PSORIASIS, ACUTE ANTERIOR UVEITIS, AND INFLAMMATORY BOWEL DISEASE PRESENTING WITH UNDIAGNOSED BACK PAIN}

Walter P Maksymowych ${ }^{1,2}$, Raj Carmona ${ }^{3}$, James Yeung ${ }^{4}$, Jon Chan ${ }^{5}$, Liam Martin $^{6}$, Sibel Aydin ${ }^{7}$, Dianne Mosher ${ }^{6}$, Ariel Masetto ${ }^{8}$, Stephanie Keeling ${ }^{1}$, Olga Ziouzina ${ }^{6}$, Sherry Rohekar ${ }^{9}$, Joel Paschke ${ }^{2}$, Amanda Carapellucci ${ }^{2}$, Robert G Lambert ${ }^{1} .{ }^{1}$ University of Alberta, Edmonton, Canada; ${ }^{2}$ CaRE Arthritis, Edmonton, Canada; ${ }^{3}$ McMaster University, Hamilton, Canada; ${ }^{4}$ James Yeung Rheumatology, Vancouver, Canada; ${ }^{5}$ Artus Health Center, Vancouver, Canada; ${ }^{6}$ University of Calgary, Calgary, Canada; ${ }^{7}$ University of Ottawa, Ottawa, Canada ${ }^{8}$ University of Sherbrooke, Sherbrooke, Canada; ${ }^{9}$ Lawson Health Research Institute, London, Canada

Background: There is limited prospective data as to the frequency of axial spondyloarthritis $(\mathrm{axSpA})$ in unselected patients referred to rheumatologists with undiagnosed back pain. It is also unclear which clinical features discriminate between axSpA and non-specific causes of back pain that might inform the development of a screening strategy.

Objectives: To determine the prevalence of axSpA in unselected patients referred with undiagnosed back pain presenting with AAU, psoriasis, or colitis and determine which clinical characteristics define patients with axSpA.

Methods: The multicenter Screening for Axial Spondyloarthritis in Psoriasis, Iritis, and Colitis (SASPIC) Study is aimed at facilitating early detection of axial SpA. First and last patients were recruited on February 2013 and March 2018, respectively. Consecutive patients $\leq 45$ years of age with $\geq 3$ months undiagnosed back pain with any one of psoriasis, $\mathrm{AAU}$, or colitis had routine clinical evaluation by a rheumatologist for axial SpA and MRI evaluation ordered per rheumatologist decision. Differences in clinical characteristics between those who were diagnosed as axSpA or non-specific back pain were analyzed using chi-squared and ttests.
Results: A total of 246 patients were recruited, $47.6 \%$ were diagnosed with axSpA, and these included $68.5 \%$ of B27 positive patients (Table 1). Diagnosis of axSpA was established in $45.7 \%, 61.6 \%$, and $40.2 \%$ of patients, while ASAS classification criteria were met by $26.1 \%, 71.2 \%$, and $27.6 \%$ of patients with psoriasis, AAU, and IBD, respectively. Features of inflammatory back pain, male gender, and B27 positivity, but not physical measures discriminated axSpA from other causes of back pain (Table 2).

Abstract THU0392 -Table 1

\begin{tabular}{lccc}
\hline & Psoriasis & AAU & IBD \\
\hline Total number (\%) & $46(18.7 \%)$ & $73(29.7 \%)$ & $127(51.6 \%)$ \\
Age, mean (SD) years & $36.7(6.0)$ & $34.0(5.8)$ & $34.0(7.3)$ \\
Males, N (\%) & $24(52.2 \%)$ & $41(56.2 \%)$ & $64(50.4 \%)$ \\
Symptom Duration, mean (SD) years & $7.7(7.7)$ & $8.7(6.7)$ & $6.3(5.9)$ \\
B27+, N (\%) & $10(21.7 \%)$ & $51(69.9 \%)$ & $28(22.0 \%)$ \\
Family history of SpA, N (\%) & $15(32.6 \%)$ & $15(20.5 \%)$ & $20(15.7 \%)$ \\
Enthesitis, N (\%) & $15(32.6 \%)$ & $13(17.8 \%)$ & $39(30.7 \%)$ \\
Peripheral arthritis, N (\%) & $13(28.3 \%)$ & $2(2.7 \%)$ & $5(3.9 \%)$ \\
Dactylitis, N (\%) & $4(8.7 \%)$ & $2(2.7 \%)$ & $3(2.4 \%)$ \\
Radiographic sacroiliitis,\% & $6.5 \%$ & $23.3 \%$ & $10.2 \%$ \\
Axial SpA rheumatologist diagnosis,\% & $45.7 \%$ & $61.6 \%$ & $40.2 \%$ \\
Axial SpA diagnosis and B27+,\% & $15.2 \%$ & $52.1 \%$ & $12.6 \%$ \\
Meets ASAS criteria,\% & $26.1 \%$ & $71.2 \%$ & $27.6 \%$ \\
\hline
\end{tabular}

Abstract THU0392 -Table 2.

\begin{tabular}{lccc}
\hline Demographics & $\begin{array}{c}\text { axSpA YES } \\
(\mathbf{n = 1 1 7},\end{array}$ & $\begin{array}{c}\text { Not axSpA } \\
(\mathbf{n = 1 2 9 ,}\end{array}$ & P value \\
& $\mathbf{4 7 . 6 \% )}$ & $\mathbf{5 2 . 4 \% )}$ & \\
\hline Male, N (\%) & $72(61.5 \%)$ & $57(44.2 \%)$ & 0.006 \\
Mean (SD) age, years & $33.7(6.7)$ & $35.2(6.7)$ & $\mathrm{ns}$ \\
Inflammatory Back Pain Yes, N (\%) & $102(87.2 \%)$ & $72(55.8 \%)$ & $<0.00001$ \\
Duration stiffness > 60 mins, N (\%) & $57(48.7 \%)$ & $30(23.3 \%)$ & 0.001 \\
Nocturnal awakening 2nd half of night, N (\%) & $72(61.5 \%)$ & $51(39.5 \%)$ & 0.001 \\
Alternating buttock pain, N (\%) & $53(45.3 \%)$ & $21(16.3 \%)$ & $<0.00001$ \\
Improvement with exercise but not rest, N & $77(65.8 \%)$ & $48(37.2 \%)$ & $<0.00001$ \\
(\%) & & & \\
Respond to NSAID within 48 hrs, N (\%) & $58(49.6 \%)$ & $59(45.7 \%)$ & $\mathrm{ns}$ \\
Family history of SpA, N (\%) & $22(18.8 \%)$ & $28(21.7 \%)$ & $\mathrm{ns}$ \\
B27 positive & $61(52.1 \%)$ & $28(21.7 \%)$ & $<0.00001$ \\
Elevated CRP (> 6.0mg/L) & $43(36.8 \%)$ & $32(24.8 \%)$ & 0.042 \\
Radiographic sacroiliitis, N (\%), local readers & $54(46.2 \%)$ & $7(5.4 \%)$ & $<0.00001$ \\
\hline
\end{tabular}

Conclusion: Patients with extra-articular manifestations and undiagnosed back pain have a high prevalence of axSpA and referral to a rheumatologist should constitute standard of care, especially if B27 positive.

Disclosure of Interests: Walter P Maksymowych Grant/research support from: AbbVie, Pfizer, Janssen, Novartis, Consultant for: AbbVie, Eli Lilly, Boehringer, Galapagos, Janssen, Novartis, Pfizer and UCB Pharma; Chief Medical Officer for Canadian Research and Education Arthritis, Raj Carmona Grant/research support from: Amgen, Abbvie, Jannsen, Consultant for: Amgen, Abbvie, BMS, El Lilly, Merck, Novartis, Jannsen, Takeda, UCB, James Yeung: None declared, Jon Chan Grant/research support from: Janssen, UCB, Novartis, Pfizer, Celgene, Consultant for: Amgen, Celgene, Eli Lilly, Janssen, Amgen, Abbvie, Novartis, Pfizer, UCB, Sandoz, Merck, Liam Martin: None declared, Sibel Aydin Consultan for: Abbvie, Celgene, UCB, Novartis, Jannsen, Sanofi, Dianne Mosher: None declared, Ariel Masetto Grant/research support from: Amgen, Sanofi, Consultant for: Sanofi, Pfizer, Bristol-Myers Squibb, Novartis, Boehringer Ingelheim, Speakers bureau: Novartis, Stephanie Keeling Consultant for: AbbVie. Pfizer, Eli Lily, Janssen, Amgen, Astrzeeneca, UCB., Olga Ziouzina: None declared, Sherry Rohekar Consultant for: Abbvie, Amgen, BMS, Celgene, Eli-Lilly, Janssen, Merck, Novartis, Pfizer, Roche, Sanofi, UCB, Joel Paschke: None declared, Amanda Carapellucci: None declared, Robert G Lambert Consultant for: Bioclinica, Parexel, Abbvie

[3] DOI: 10.1136/annrheumdis-2019-eular.6299 